\title{
Necrotizing Fasciitis of the Left Lower Limb Complicated with the Abscess of Retroperitoneal Space: Case Report Presentation and a Retrospective Study
}

\section{Chao Wang}

Qilu Hospital of Shandong University

Fan Zhang ( $\square$ zhangfan@qiluhospital.com )

Qilu Hospital of Shandong University Qingdao https://orcid.org/0000-0001-5993-9117

Zhensheng Hu

Qilu Hospital of Shandong University

\section{Primary research}

Keywords: necrotizing fasciitis, the abscess of retroperitoneal space, septic shock, vacuum-assisted closure

Posted Date: June 14th, 2021

DOl: https://doi.org/10.21203/rs.3.rs-425174/v1

License: (c) (1) This work is licensed under a Creative Commons Attribution 4.0 International License.

Read Full License 


\section{Abstract}

Background: Necrotizing fasciitis(NF) is a severe progressive infectious disease where a synergistic action of multiple bacteria results in suppurative necrosis of the skin and soft tissue. Despite being a relatively uncommon infection, its mortality is significantly high. In this case report, we describe the clinical presentation, management and outcome of a patient with NF of the left lower limb complicated with the abscess of retroperitoneal space and ensuing septic shock and dysfunction of heart and liver. Finally, we analyzed six cases we have treated before including this one and a retrospective study was performed.

Case presentation: A 69-year-old male patient, complaining about the pain of left lower limb and high fever due to uncertain reasons, featuring the tenderness of affected limb and left lower abdomen, was diagnosed with the NF complicated with the abscess of retroperitoneal space. The patient then develop septic shock and dysfunction of heart and liver. After repeated debridement of necrosis tissue, in combination with multiple antibiotics, laboratory test methods and the vacuum-assisted closure(VAC) therapy, the patient survived, gradually improved and finally got a full recovery.

Methods: A retrospective study was performed on six patients with NF of unilateral lower limb from March 2018 to October 2019. All patients were given systemic antibiotics and nutrition support. During the first stage, repeated surgical debridement with negative-pressure wound therapy(NPWT) was performed. Direct suture of the wound was performed in the second stage.

Results: The incision healed well in all patients, and no infection or necrosis occurred in the wound. During the follow-up of 6.5 months (range, 5-9 months), no recurrence of infection or incision rupture occurred.

Discussion: Although prompt diagnosis and adequate antibiotic therapy are basic for the treatment of patients with NF, early and repeated surgical intervention is vital for a favorable outcome. Thus, adjuvant treatment for NF such as negative pressure wound therapy (NPWT) using the VAC are very useful to accelerate wound healing.

Conclusions: Prompt diagnosis, adequate antibiotic therapy and more crucially, early and repeated surgical debridement of the necrotic tissue combined with VAC therapy play a collaborative role in the successful treatment of NF.

\section{Background}

Necrotizing fasciitis (NF) is a severe progressive infectious disease that primarily involves the fascia and subcutaneous tissue where a synergistic action of multiple bacteria (including aerobic bacteria and anaerobic bacteria) results in suppurative necrosis of the skin and soft tissue. ${ }^{1}$ It can affect all parts of body and the lower extremities are the most common sites of infection. ${ }^{2}$ Its pathogenesis is characterized by rapid horizontal spread of infection along the deep fascial planes, and tissue ischemia and 
liquefactive necrosis due to release of bacterial toxins, as well as fulminant systemic disease including septic shock and death. ${ }^{3}$

To manage sepsis and septic shock in this setting, complex strategies and interventional methods have been deployed in recent years, including combination antimicrobial therapy, infection source control, and other intensive supportive therapies, whose role is well established. ${ }^{4}$

We present a case of necrotizing fasciitis complicated with the abscess of retroperitoneal space and ensuing septic shock and dysfunction of heart and liver, with multiple bacteria isolated including multidrug resistant Acinetobacter baumannii. In this scenario, it is useful to illustrate how important the role of each of these treatments is in the NF management.

This work has been reported in line with the SCARE criteria. ${ }^{5}$

\section{Case Presentation}

A 69-year-old male patient with a history of one year hypertension and 20 years lumbar disc herniation, presented with ten days pain of left lower limb and fever without certain reason, first admitted to local hospital and diagnosed with lumbar disc herniation, was transferred to the ICU at Qilu hospital of Shandong University after having fever up to $39.2^{\circ} \mathrm{C}$ on 9 June 2019.

The CT of pelvis and lower limbs from local hospital showed extensive subcutaneous pneumatosis and soft tissue edema of left lower limb and retroperitoneal space involving iliac fossa and inguinal region(Fig. 1,2,3,4). The blood test revealed white blood cell(WBC) $33.41^{*} 10^{\wedge} 9 / \mathrm{L}$, neutrophil(NEU) $30.84^{\star} 10^{\wedge} 9 / \mathrm{L}$ and procalcitonin(PCT) $1.34 \mathrm{ng} / \mathrm{ml}$. And the physical examination found positive sign of left knee abduction stress test, left hip abduction and external rotation test and straight leg raising test. All the above indicated us that the patient had a severe soft tissue infectious condition of left lower limb and retroperitoneal space.

(The red arrows in Fig. 1,2,3,4 respectively revealed the lesion tissue of pelvis, retroperitoneal space, hip joint and left lower limb.)

On admission we immediately started continuous ECG monitoring,

pulse oximetry, non-invasive blood pressure measurements and admission examination revealed the following: a weight of $70 \mathrm{~kg}$, a height of $173 \mathrm{~cm}$, a temperature of $35.4^{\circ} \mathrm{C}$, a heart rate of $108 \mathrm{beats} / \mathrm{min}$, a respiratory rate of 17 breaths/min, a blood pressure of $94 / 69 \mathrm{mmHg}$, and a SaO2 of $99 \%$. The patient was in a listless state. Results of the laboratory examinations are shown in Table 1. At the same time, we treated the patient with Meropenem $1 \mathrm{~g}$ IV every 8 hours and Linezolid $0.6 \mathrm{~g}$ IV every 12 hours according to the empirical antibiotic therapy, in combination with fluid replacement, analgesic treatment, Gastric mucosal protection, myocardiac nutrition and respiratory management. 
Table 1

Results of Laboratory Examinations

\begin{tabular}{|lll|}
\hline Type of test & Patient's value & Normal range \\
\hline white blood cell count(WBC) & $17.38^{\star} 10^{\wedge} 9 / \mathrm{L}$ & $3.5-9.5^{\star} 10^{\wedge} 9 / \mathrm{L}$ \\
\hline neutrophil ratio(NEU\%) & $91.5 \%$ & $40-75 \%$ \\
\hline level of C reactive protein(CRP) & $191 \mathrm{mg} / \mathrm{L}$ & $<8 \mathrm{mg} / \mathrm{L}$ \\
\hline procalcitonin(PCT) & $5.41 \mathrm{ng} / \mathrm{ml}$ & $<0.1 \mathrm{ng} / \mathrm{ml}$ \\
\hline erythrocyte sedimentation rate(ESR) & $31 \mathrm{~mm} / \mathrm{h}$ & $0-15 \mathrm{~mm} / \mathrm{h}$ \\
\hline pH of arterial blood & 7.52 & $7.35-7.45$ \\
\hline lactic acid of arterial blood & $1.8 \mathrm{mmol} / \mathrm{L}$ & $0.5-2.2 \mathrm{mmol} / \mathrm{L}$ \\
\hline HCO ${ }^{-}{ }^{-}$of arterial blood & $20.4 \mathrm{mmo} / \mathrm{L}$ & $21-28 \mathrm{mmol} / \mathrm{L}$ \\
\hline glucose & $9.5 \mathrm{mmo} / \mathrm{L}$ & $3.9-6.1 \mathrm{mmo} / \mathrm{L}$ \\
\hline alanine aminotransferase(ALT) & $15 \mathrm{U} / \mathrm{L}$ & $<35 \mathrm{U} / \mathrm{L}$ \\
\hline aspartate aminotransferase(AST) & $12 \mathrm{U} / \mathrm{L}$ & $<35 \mathrm{U} / \mathrm{L}$ \\
\hline albumin(ALB) & $19.4 \mathrm{~g} / \mathrm{L}$ & $35-55 \mathrm{~g} / \mathrm{L}$ \\
\hline albumin/globulin (A/G) & 0.7 & $1.2-2.4$ \\
\hline total bilirubin(TBIL) & $15.2 \mathrm{mmol} / \mathrm{L}$ & $5-21 \mathrm{mmol} / \mathrm{L}$ \\
\hline direct bilirubin(DBIL) & $9 \mathrm{mmol} / \mathrm{L}$ & $<6 \mathrm{mmol} / \mathrm{L}$ \\
\hline prothrombin time(PT) & $17.7 \mathrm{~s}$ & $11-14.5 \mathrm{~s}$ \\
\hline activated partial thromboplastin time(APTT) & 37.2 & $28-45 \mathrm{~s}$ \\
\hline fibrinogen degradation product(FDP) & $6.42 \mathrm{ug} / \mathrm{L}$ & $2-4 \mathrm{~g} / \mathrm{L}$ \\
\hline (1-3)- $\beta$-D Glucan, Fungus(G test) & negative & $\mathrm{NA}$ \\
\hline serological test of aspergillus (GM test) & negative & $\mathrm{NA}$ \\
\hline human Immunodeficiency Virus & negative & $\mathrm{NA}$ \\
\hline blood culture(after 3 days) & negative & $\mathrm{NA}$ \\
\hline sputum culture(after 3 days) & $\mathrm{NA}$ \\
\hline
\end{tabular}

On the second day CT scan of head and chest showed bilateral lungs inflammation with mild pleural effusion and emphysema. In order to improve the patient's immunity and prevent the infection from spreading, human serum albumin and immunoglobulin were added into treatment. Based on such data, 
after multidisciplinary consults, a debridement and exploration of pelvis, hip and left lower limb, followed by vacuum-assisted closure (VAC) therapy(KCl Inc., San Antonio, Texas, USA), was at last performed(Fig. $5,6,7,8)$. However, intraoperative microbiological sampling revealed nothing.

(Fig. 5, The marker line of left lower limb. Figure 6, The marker line of left lower abdomen. Figure 7, The abscess of left lower limb during the first surgery. Figure 8 , The wound after debridement during the first surgery. )

In the following days, the patient's condition improved and laboratory examinations showed the decline of inflammatory indicators in varying degrees. Therefore, after five days in ICU, the patient was transferred to the general ward in our Department of Burns and Plastic Surgery and meanwhile Meropenem regime was changed from every 8 hours to every 12 hours.

On the sixth day, a CT scan of chest,abdomen,pelvis and lower limbs was performed and still showed subcutaneous pneumatosis of left lower limb and retroperitoneal space. So the next day another debridement was carried out, followed by VAC and intraoperative microbiological sampling again. What should be mentioned is that a incident of temporary hypotension occurred during the surgery and was successfully relieved. However,Just two hours after the patient being delivered to the ward, the hypotension got back and worsen. BP 75/49mmHg, HR 120/min, Sp02 70\%, with cold skin of the extremities, thick and coarse breath sounds and wet rales in bilateral lungs, restless and delirium state of the patient, five seconds the capillary refill time exceeding, we immediately realized that septic shock complicated with dysfunction of heart happened and almost at once we start fluid resuscitation, antishock therapy with Norepinephrine $(0.05 \mathrm{mg} / \mathrm{kg} / \mathrm{min}, 24 \mathrm{~h}$ maintenance). Meanwile, the laboratory examinations were rechecked and the results were showed in Table 2. After two hours of treatment, the blood pressure of the patient gradually recovered and the heart rate decreased. 
Table 2

Results of Laboratory Examinations

\begin{tabular}{|lll|}
\hline Type of test & Patient's value & Normal range \\
\hline white blood cell count(WBC) & $37.83^{*} 10^{\wedge} 9 / \mathrm{L}$ & $3.5-9.5^{\star} 10^{\wedge} 9 / \mathrm{L}$ \\
\hline neutrophil ratio(NEU\%) & $83.8 \%$ & $40-75 \%$ \\
\hline level of C reactive protein(CRP) & $85.94 \mathrm{mg} / \mathrm{L}$ & $<8 \mathrm{mg} / \mathrm{L}$ \\
\hline procalcitonin(PCT) & $3.67 \mathrm{ng} / \mathrm{ml}$ & $<0.1 \mathrm{ng} / \mathrm{ml}$ \\
\hline B-type natriuretic peptide(BNP) & $1106 \mathrm{pg} / \mathrm{ml}$ & $\mathrm{NA}$ \\
\hline pH of arterial blood & 7.49 & $7.35-7.45$ \\
\hline lactic acid of arterial blood & $5.5 \mathrm{mmol} / \mathrm{L}$ & $0.5-2.2 \mathrm{mmol} / \mathrm{L}$ \\
\hline HCO ${ }_{3}{ }^{-}$of arterial blood & $16.8 \mathrm{mmo} / \mathrm{L}$ & $21-28 \mathrm{mmol} / \mathrm{L}$ \\
\hline glucose & $5.7 \mathrm{mmol} / \mathrm{L}$ & $3.6-6.1 \mathrm{mmol} / \mathrm{L}$ \\
\hline alanine aminotransferase(ALT) & $54 \mathrm{U} / \mathrm{L}$ & $<35 \mathrm{U} / \mathrm{L}$ \\
\hline aspartate aminotransferase(AST) & $45 \mathrm{U} / \mathrm{L}$ & $<35 \mathrm{U} / \mathrm{L}$ \\
\hline albumin(ALB) & $25 \mathrm{~g} / \mathrm{L}$ & $35-55 \mathrm{~g} / \mathrm{L}$ \\
\hline albumin/globulin (A/G) & 0.73 & $1.2-2.4$ \\
\hline total bilirubin(TBIL) & $80 \mathrm{mmol} / \mathrm{L}$ & $3-22 \mathrm{mmol} / \mathrm{L}$ \\
\hline direct bilirubin(DBIL) & $40 \mathrm{mmol} / \mathrm{L}$ & $0-5 \mathrm{mmol} / \mathrm{L}$ \\
\hline
\end{tabular}

On the 12th day, intraoperative microbiological sampling yielded methicillin-resistant staphylococci(MRS) isolates and showed sensitive to vancomycin. Antibiotic therapy was therefore modifed. Meropenem and Linezolid were substituted with Vancomycin IV $1 \mathrm{~g}$ every $12 \mathrm{hours.}$

Regardless of the clinical improvement after three more surgical debridements of necrotic soft tissue and followed VAC, the patient persisted with a irregular fever(Fig. 9) and inflammation condition (Fig. 10) which the blood test had indicated. Multiple sampling during the surgery finally revealed the carbapenems-resistant Acinetobacter baumanii(CRAB) isolate which was only sensitive to Tigecycline, and Eikenella corrodens isolate. And then Tigecycline (IV 50mg every 12 hours)was added to antibiotic therapy.

In the following days, the patient got better gradually and the laboratory examinations showed a consequent improvement. Finally the skin suturing was carried out and the patient discharged from hospital on the 68th day after a full recovery. After suffering all these traumatic interventions, the patient felt grateful deeply and send his gratitude to us for saving his life. 


\section{Methods}

This retrospective study was approved by the ethics committee. All medical records including relevant images were retrieved after obtaining written informed consent from the patients. Six patients were selected from the Burn and Plastic Surgery Department of Qilu Hospital of Shandong University between March 2018 and October 2019. The inclusion criteria were a definite diagnosis of NF, wound debridement without other surgical treatment, and complete treatment in Qilu Hospital of Shandong University. Patients whose treatment was incomplete or who were lost to follow-up were excluded from the study. The demographic and clinical characteristics of the patients are summarized in Table 3.

Table 3

The demographic and clinical characteristics of the patients

\begin{tabular}{|c|c|c|c|c|c|c|}
\hline Patient & A & B & $\mathrm{C}$ & D & $\mathrm{E}$ & $F$ \\
\hline Age/Y & 69 & 77 & 43 & 64 & 55 & 58 \\
\hline Gender & Male & Male & Male & Male & Female & Male \\
\hline $\begin{array}{l}\text { Specific injury history } \\
\text { (Yes/No) }\end{array}$ & $\mathrm{N}$ & $\mathrm{N}$ & $Y$ & $\mathrm{~N}$ & $Y$ & $\mathrm{~N}$ \\
\hline $\begin{array}{l}\text { Days before surgical } \\
\text { treatment }\end{array}$ & 10 & 2 & 15 & 3 & 5 & 7 \\
\hline $\begin{array}{l}\text { Times of surgical } \\
\text { treatment }\end{array}$ & 6 & 3 & 3 & 4 & 2 & 3 \\
\hline $\begin{array}{l}\text { Abscess of retroperitoneal } \\
\text { space }(\mathrm{Y} / \mathrm{N})\end{array}$ & $Y$ & $\mathrm{~N}$ & $Y$ & N & $\mathrm{N}$ & $N$ \\
\hline $\begin{array}{l}\text { Main microbiological } \\
\text { sampling strains }\end{array}$ & $\mathrm{CRAB}^{\mathrm{a}}+\mathrm{MRS}^{\mathrm{b}}$ & $\begin{array}{l}\text { CRAB + } \\
\text { E.colic }\end{array}$ & K.pneu ${ }^{d}$ & $\begin{array}{l}\text { ESBLs }{ }^{e} \\
+ \text { K.pneu }\end{array}$ & K.pneu & CRAB \\
\hline Hospital stay/D & 68 & 30 & 27 & 40 & 19 & 25 \\
\hline Follow-up/M & 9 & 5 & 5 & 7 & 5 & 8 \\
\hline
\end{tabular}

\section{Results}

Five patients were male, and one patient was female, with a mean age of 61 years (range, 43-77 years). Two cases have specific injury history while others are not traceable. All the cases were diagnosed as necrotizing fasciitis with unilateral lower limb that involved subcutaneous tissue, using physical examination and imaging examinations. The secretion samples of each patient were obtained and 
cultured. The results showed CRAB was observed in three cases, K.pneu was observed in three cases. MRS, E.coli and ESBLs was observed in one case respectively.

In all six patients, no recurrence of infection or incision rupture occurred was observed during the followup of 6.5 months (range, 5-9 months) after discharge(Fig. 3).

\section{Discussion}

Necrotizing fasciitis is an uncommon but severe life threatening infectious disease. The process is marked by necrosis of the superficial fascia, neutrophil infiltration of the deep dermis and fascia, thrombosis of the cutaneous microcirculation and the presence of the infectious organism in the necrotic tissue. ${ }^{6}$ The clinical progression is often underestimated for life-threatening incidents such as septic shock in our case could occur.

The etiology is still not fully understood and cannot be identified

in many cases, ${ }^{2}$ so it is easy to delay diagnosis just like this case. ${ }^{7,8}$ Table 3 shows there's no specificity in pathogens of our NF patients. The male in our case did not display any special contact or past history and essentially present with fever and pain, which implied the patient might have suffered from a previous infection. Meanwile, it is very important to identify pathogens by repeated sampling and laboratory examinations like this case in order to guide the antibiotic therapy.

As we can see in the Table 3, the patients A and C, who did not got early surgical treatments, had developed into the abscess of retroperitoneal space, which indicate that although prompt diagnosis and adequate antibiotic therapy are basic for the treatment of patients with NF, early and repeated surgical intervention is vital for a favorable outcome. However, there are no randomized clinical controlled trial analyzing the timing or extent of surgical debridement. ${ }^{9}$

The adjuvant treatment for NF is negative pressure wound therapy (NPWT) using the vacuum assisted closure (VAC), which is a well-known wound care system for the treatment of complex wounds and has achieved good results. It has been developed as an alternative to the conventional would dressing change to accelerate the debridement and healing of complex wounds. ${ }^{10,11,12}$ The cyclical application of negative pressure can accelerate wound healing, where optimized blood flow increases local oxygenation and promotes angiogenesis, decreased local tissue edema and accelerated removal of excessive fluid from the wound bed, which in turn reduces bacterial contamination. ${ }^{13,14,15}$ However, it has been discussed less common on the necrotizing fasciitis treatment with NPWT.

\section{Conclusions}

Despite being a relatively uncommon infection, necrotizing fasciitis should be highlighted to raise the awareness of clinicians in order to prevent delayed diagnosis. Prompt diagnosis, adequate antibiotic therapy and more crucially, early and repeated surgical debridement of the necrotic tissue combined with 
NPWT therapy play a collaborative role in the successful treatment of NF. Outcomes depend on the promptness of diagnosis, surgical treatment and management of postoperative complications.

\section{Abbreviations}

NF -- necrotizing fasciitis

VAC -- vacuum-assisted closure

NPWT -- negative pressure wound therapy

WBC -- white blood cell

NEU -- neutrophil

PCT -- procalcitonin

MRS -- methicillin-resistant staphylococci

CRAB -- carbapenems-resistant Acinetobacter baumanii

E.coli -- Escherichia coli

K.pneu -- Klebsiella Pneumoniae

ESBLs -- Extended Spectrum Beta-Lactamases

\section{Declarations}

\section{Ethics approval and consent to participate}

Not applicable.

\section{Consent for publication}

Written informed consent was obtained from the patient for publication of this case report.

\section{Availability of data and materials}

The datasets used and/or analyzed during the current study are available from the corresponding author on reasonable request. 


\section{Competing Interests}

The authors declare that they have no competing interests.

\section{Funding}

The research was funded by Key Research and Development Project of

Shandong Province in Qilu Hospital of Shandong University(2017GSF218048).

Fan Zhang, the correspondence of this manuscript, lead the project and is the funder of this study. $\mathrm{He}$ designed the study and revised the manuscript.

\section{Authors'contributions}

FZ designed the study. CW and FZ participated in the patient's treantment. CW reviewed the literature, collected and analyzed the data, and wrote the manuscript. FZ and ZSH revised the manuscript. All authors read and approved the final manuscript.

\section{Acknowledgements}

We are sincerely indebted to all members in ICU and all nurses in the Department of Burns and Plastic Surgery of Qilu hospital of Shandong University, China.

\section{References}

1. Eneli I, Davies HD. Epidemiology and outcome of necrotizing fasciitis in children: an active surveillance study of the Canadian Paediatric Surveillance Program. J Pediatr. 2007;151(1):79-84. 84.e71.

2. Wang JM, Lim HK. Necrotizing fasciitis: eight-year experience and literature review[J],The Brazilian Journal of INFECTIOUS DISEASES,2014,18(2):137-143.

3. Zundel S, Lemarechal A, Kaiser P, Szavay P. Diagnosis and treatment of pediatric necrotizing fasciitis: a systematic review of the literature. Eur J Pediatr Surg. 2017;27(2):127-37.

4. Dellinger RP, Levy MM, Rhodes A, Annane D, Gerlach H, Opal SM, et al. Surviving sepsis campaign: international guidelines for management of severe sepsis and septic shock: 2012. Crit Care Med. 2013;41:580-637. I. .

5. Agha RA, Borrelli MR, Farwana R, Koshy K, Fowler AJ, Orgill DP. The SCARE 2018 statement: updating consensus Surgical CAse REport (SCARE) guidelines. Int J Surg. 2018;60:132-6. 
6. Rausch J, Foca M. Necrotizing fasciitis in a pediatric patient caused by lancefield group $\mathrm{g}$ streptococcus: case report and brief review of the literature, Case Rep. Med. 2011 (2011) 671365.

7. Wong $\mathrm{CH}$, Chang HC, Khin LW, Tan JL, Low CO. Necrotizing fasciitis: clinical presentation, microbiology, and determinants of mortality. J Bone Joint Surg Am. 2003;85:1454-60.

8. Tsai YH, Huang KC, Shen SH, Hsu WH, Peng KT, Huang TJ. Microbiology and surgical indicators of necrotizing fasciitis in a tertiary hospital of southwest Taiwan. Int J Infect Dis. 2012;16:159-65.

9. Bonne SL, Kadri SS. Evaluation and management of necrotizing soft tissue infections, Infect. Dis Clin N Am. 2017;31(3):497-511.

10. Argenta LC, Morykwas MJ. Vacuum-assisted closure: a new method for wound control and treatment: clinical experience. Ann Plast Surg. 1997;38:563-76.

11. Argenta LC, Morykwas MJ, Marks MW, DeFranzo AJ, Molnar JA, David LR. Vacuum-assisted closure: state of clinic art. Plast Reconstr Surg. 2006;117:127S-142S.

12. Morykwas MJ, Argenta LC, Shelton E, McGuirt W. Vacuum-assisted closure: a new method for wound control and treatment: animal studies and basic foundation. Ann Plast Surg. 1997;38:553-62.

13. Chiang $\mathrm{IH}$, Chang $\mathrm{SC}$, Wang $\mathrm{CH}$. Management of necrotising fasciitis secondary to abdominal liposuction using a combination of surgery, hyperbaric oxygen and negative pressure wound therapy in a patient with burn scars. Int Wound J. 2017;14:989-92.

14. Argenta LC, Morykwas MJ. Vacuum-assisted closure: a new method for wound control and treatment: clinical experience. Ann Plast Surg. 1997;38(6):563-76. discussion 577.

15. Saxena V, Hwang CW, Huang S, Eichbaum Q, Ingber D, Orgill DP. Vacuum-assisted closure: microdeformations of wounds and cell proliferation, Plast. Reconstr. Surg. 114 (5) (2004) 10861096, discussion 1097-1088.

\section{Figures}




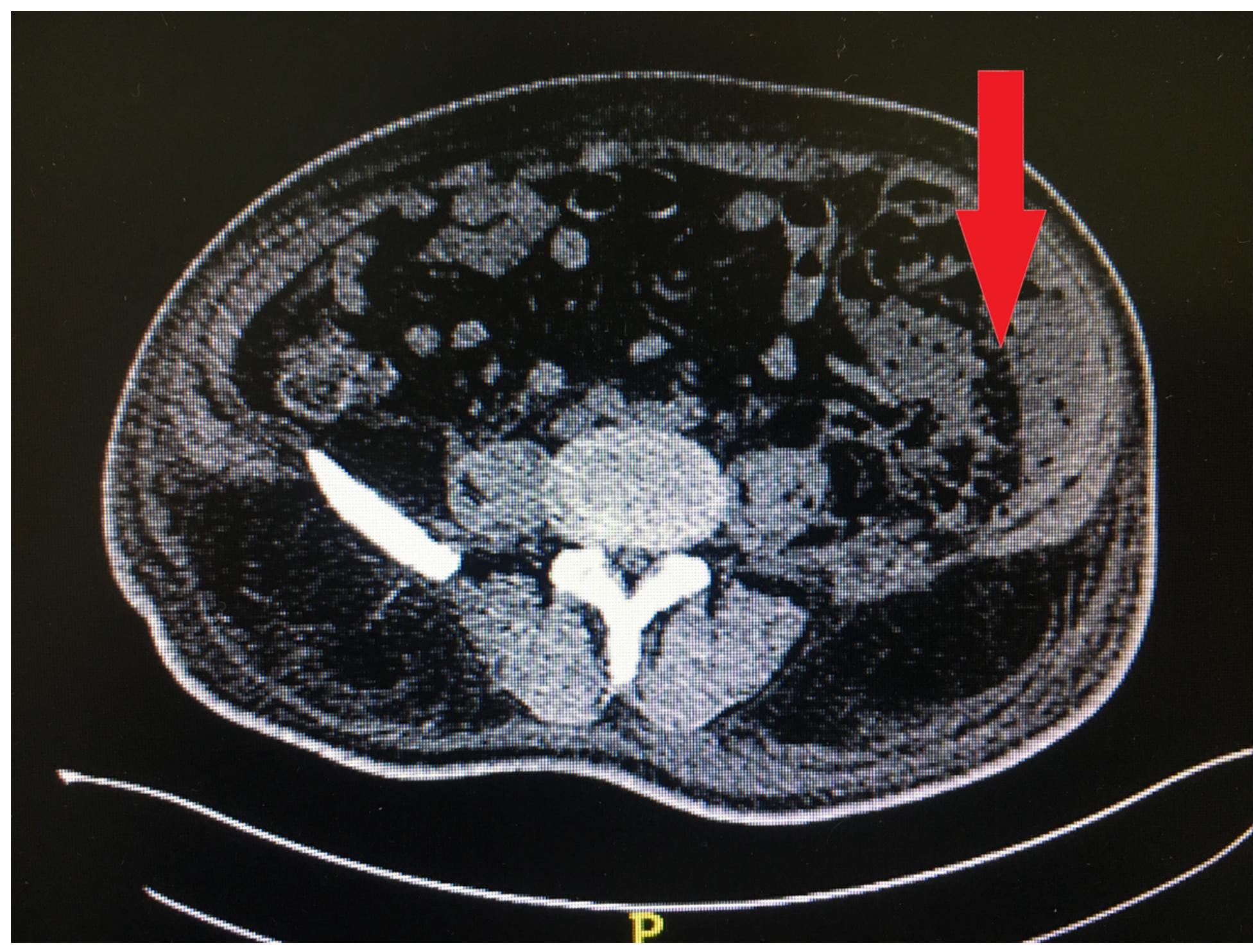

Figure 1

Please see the Manuscript file for the complete figure caption 


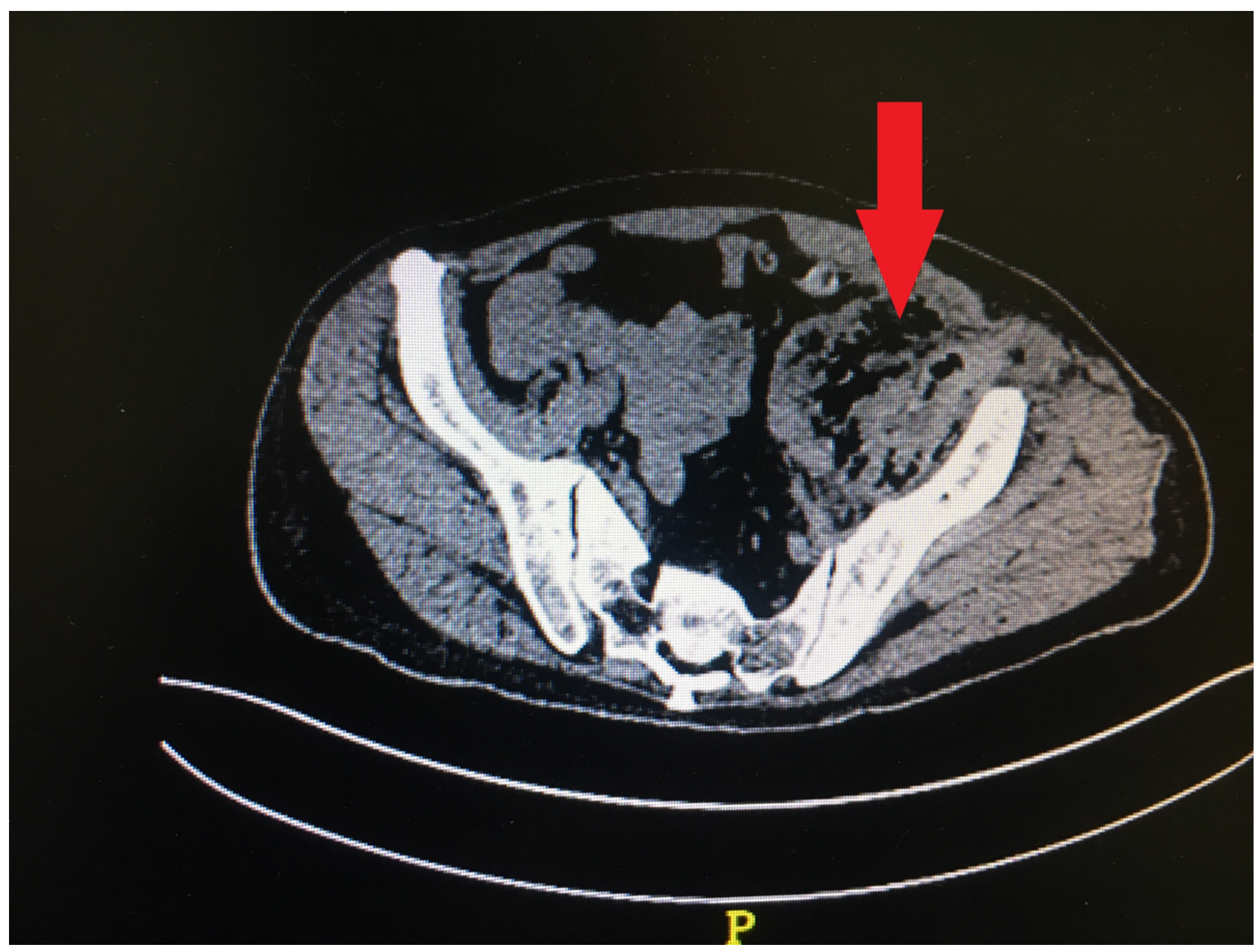

Figure 2

Please see the Manuscript file for the complete figure caption 


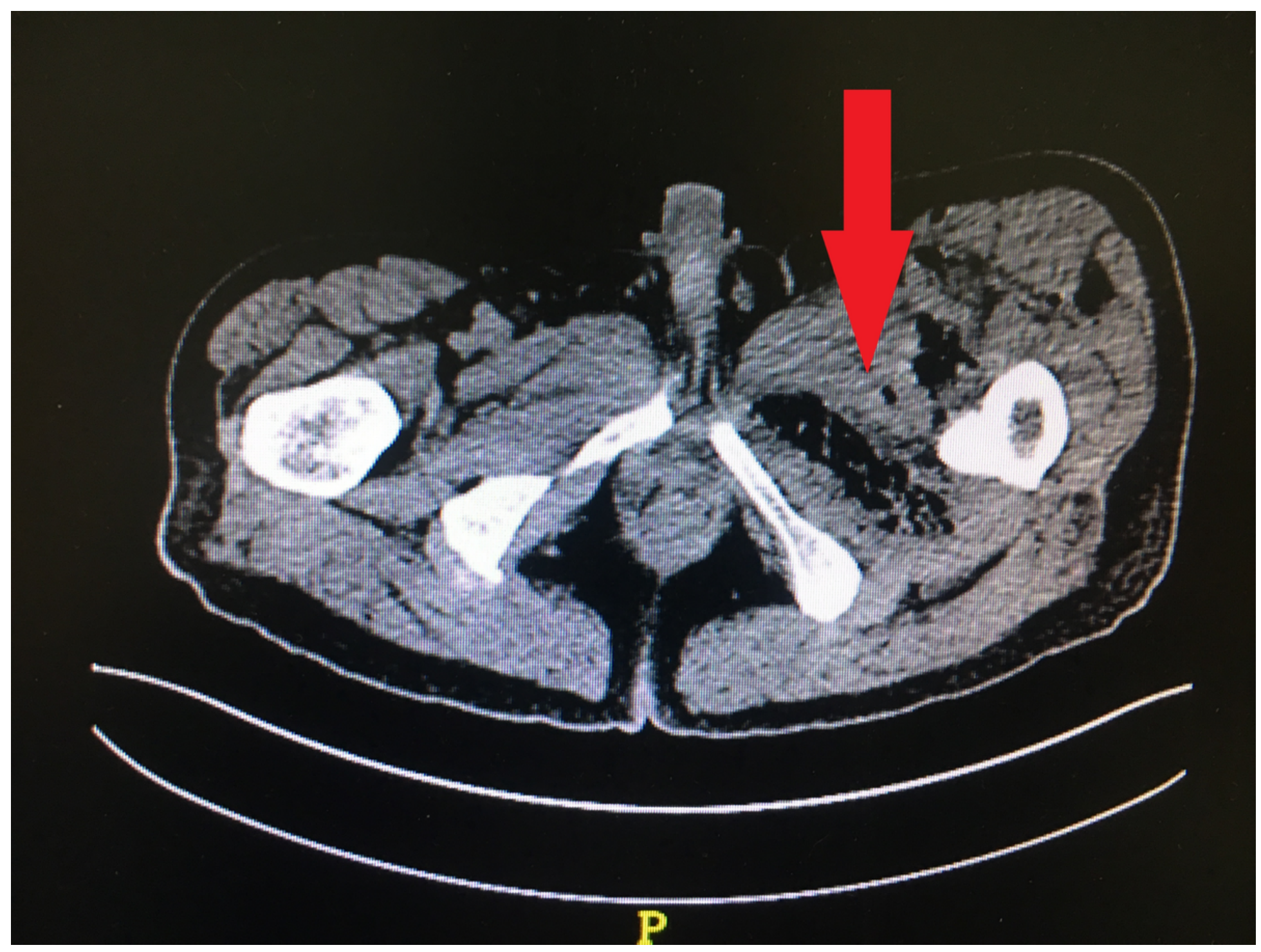

Figure 3

Please see the Manuscript file for the complete figure caption 


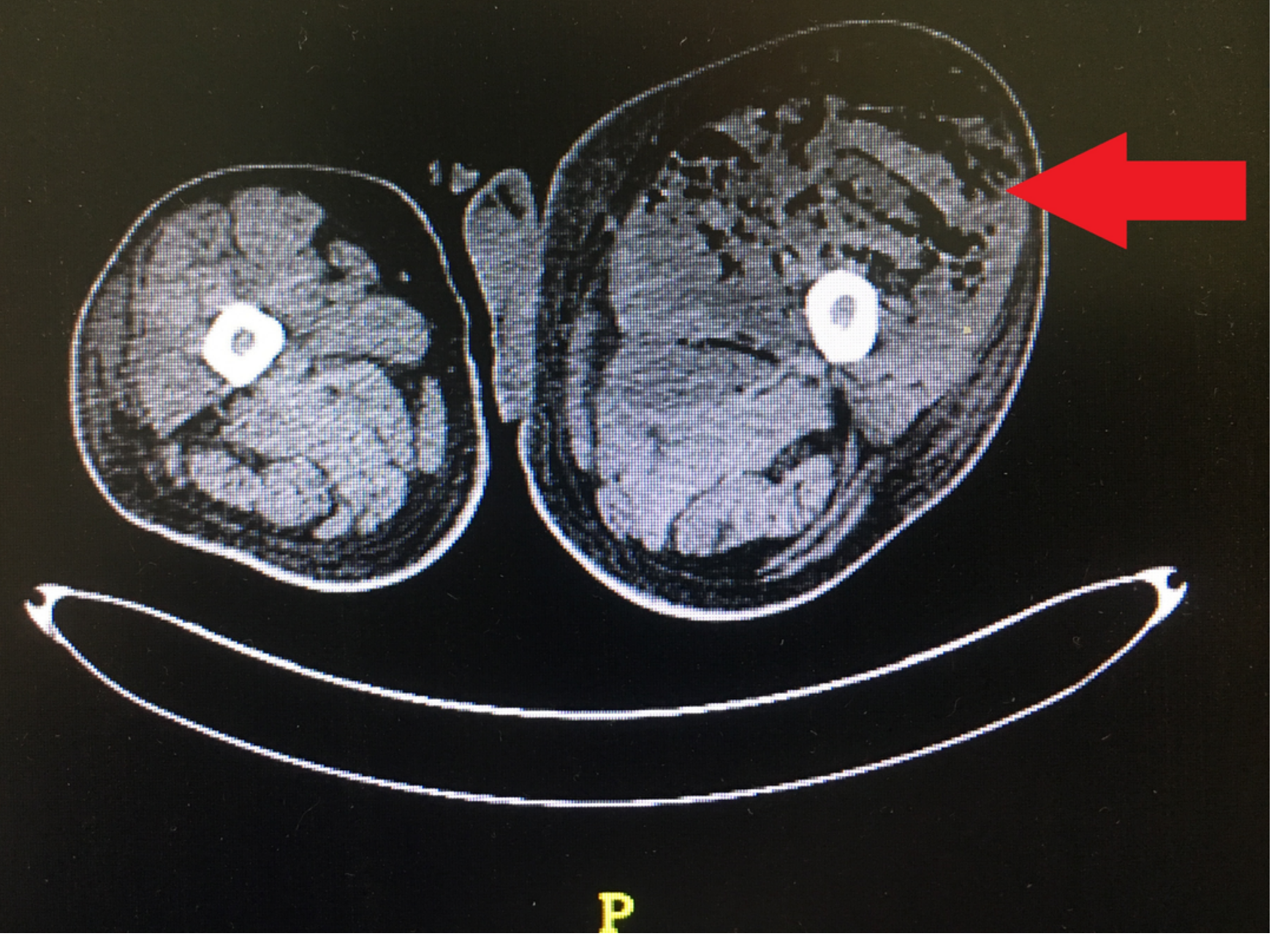

Figure 4

Please see the Manuscript file for the complete figure caption 


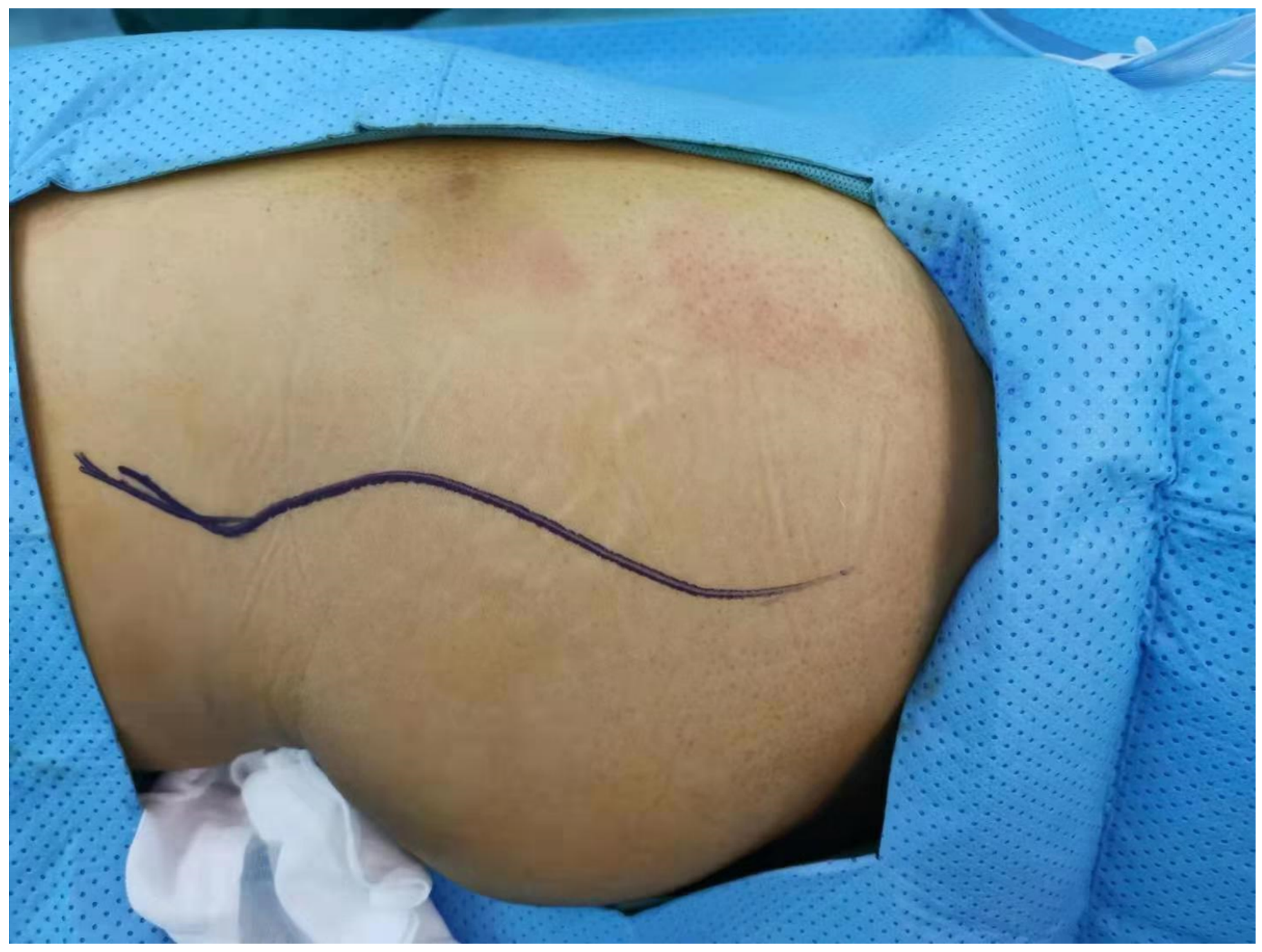

Figure 5

Please see the Manuscript file for the complete figure caption 


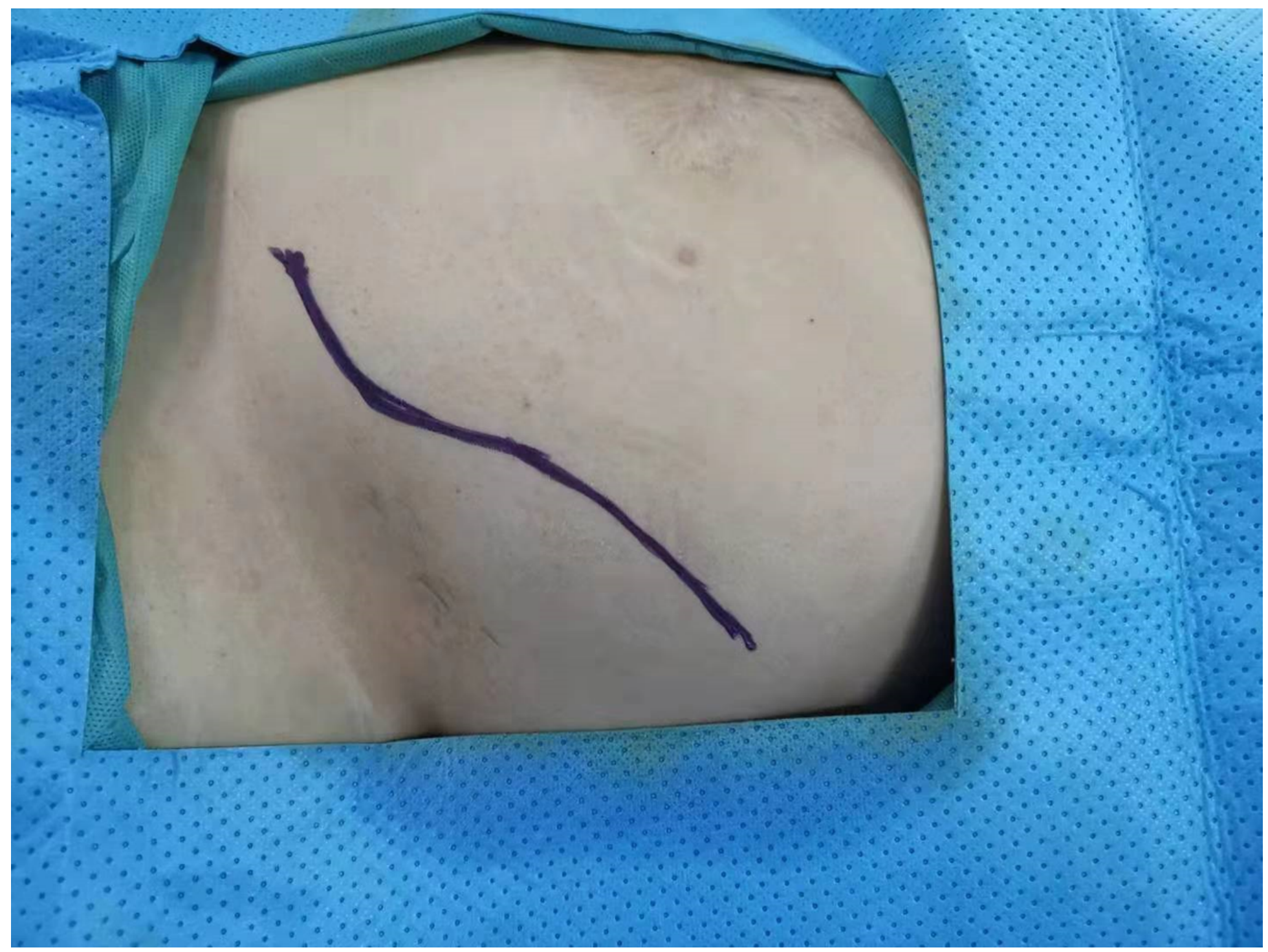

Figure 6

Please see the Manuscript file for the complete figure caption 


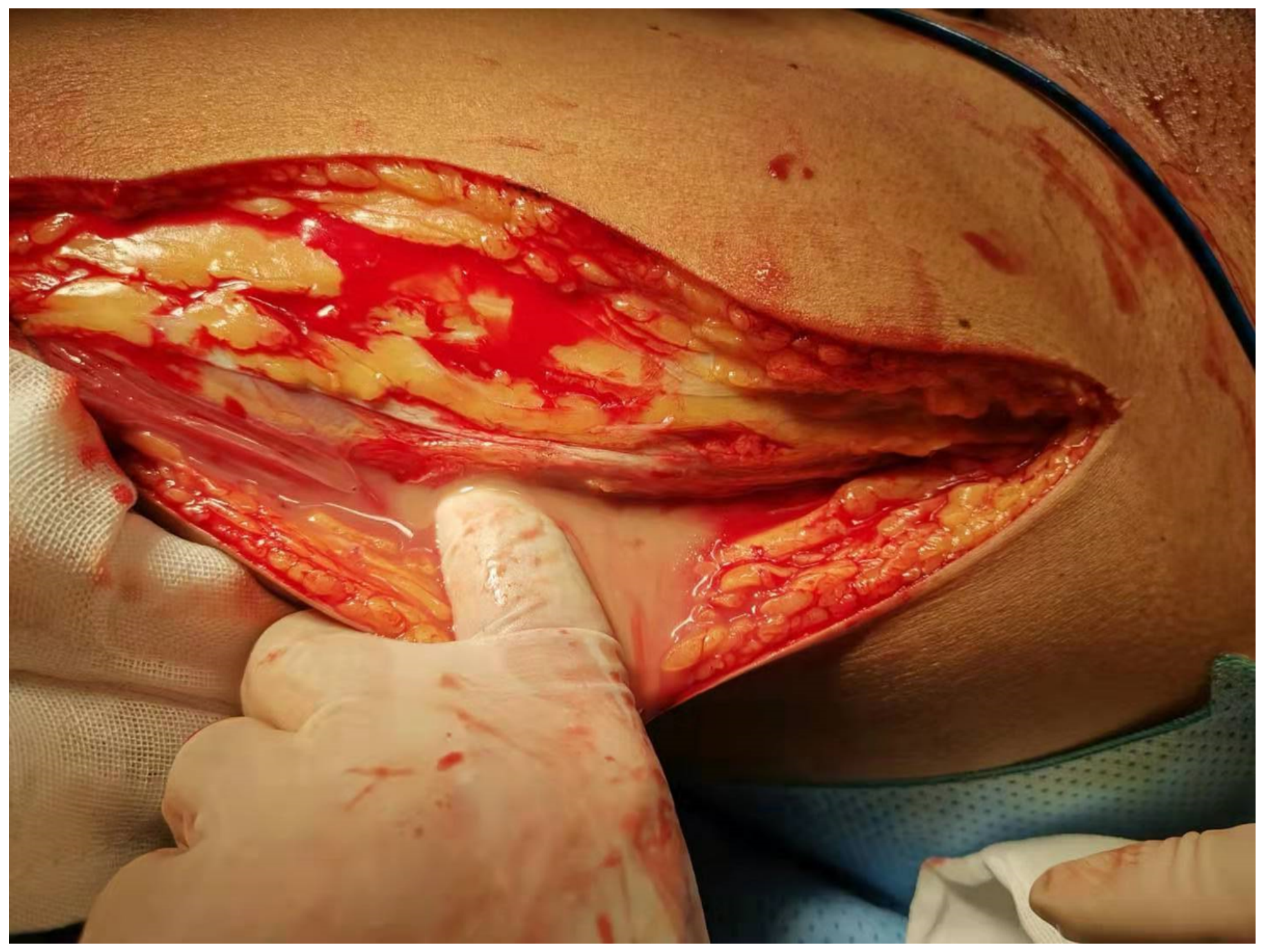

Figure 7

Please see the Manuscript file for the complete figure caption 


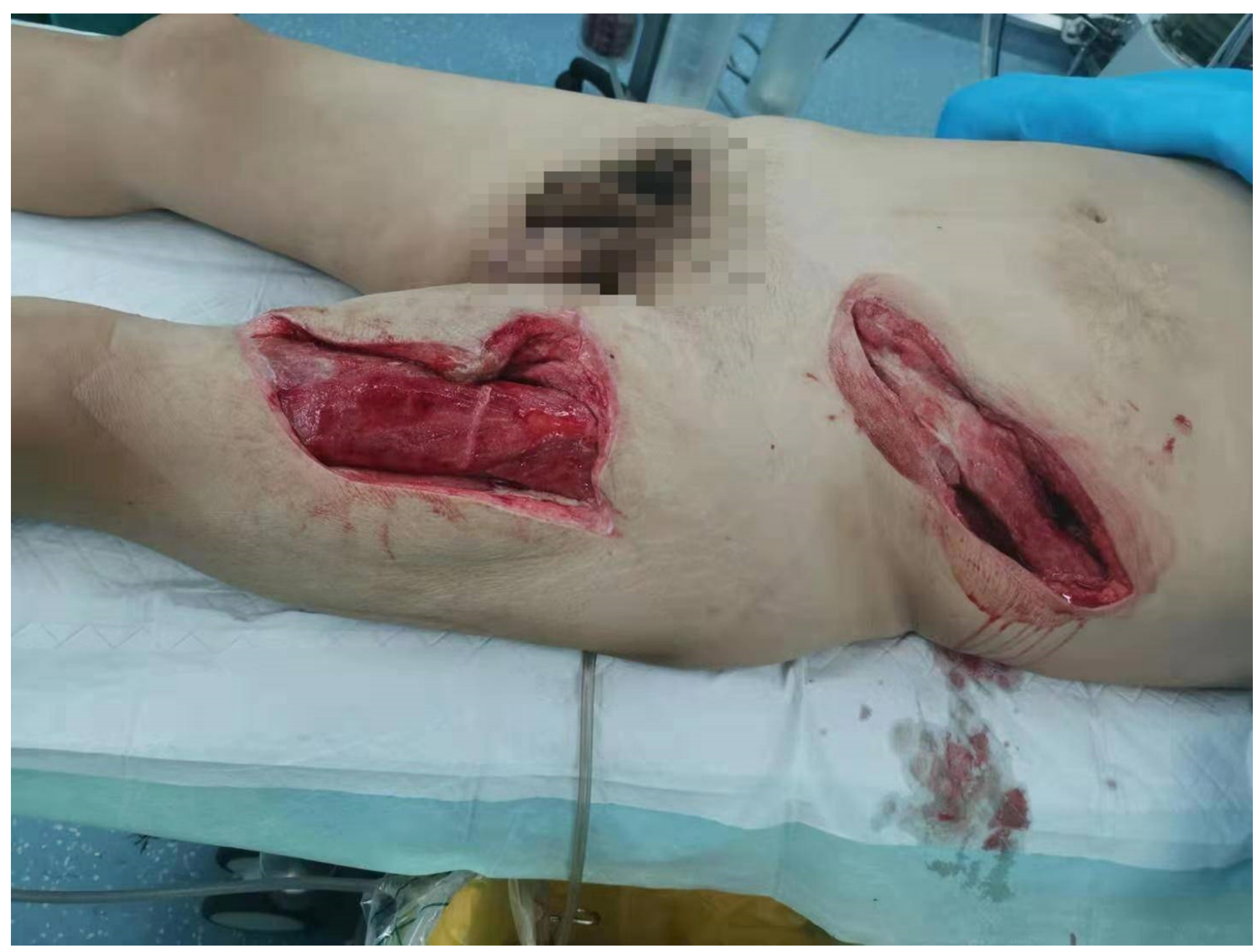

Figure 8

Please see the Manuscript file for the complete figure caption 


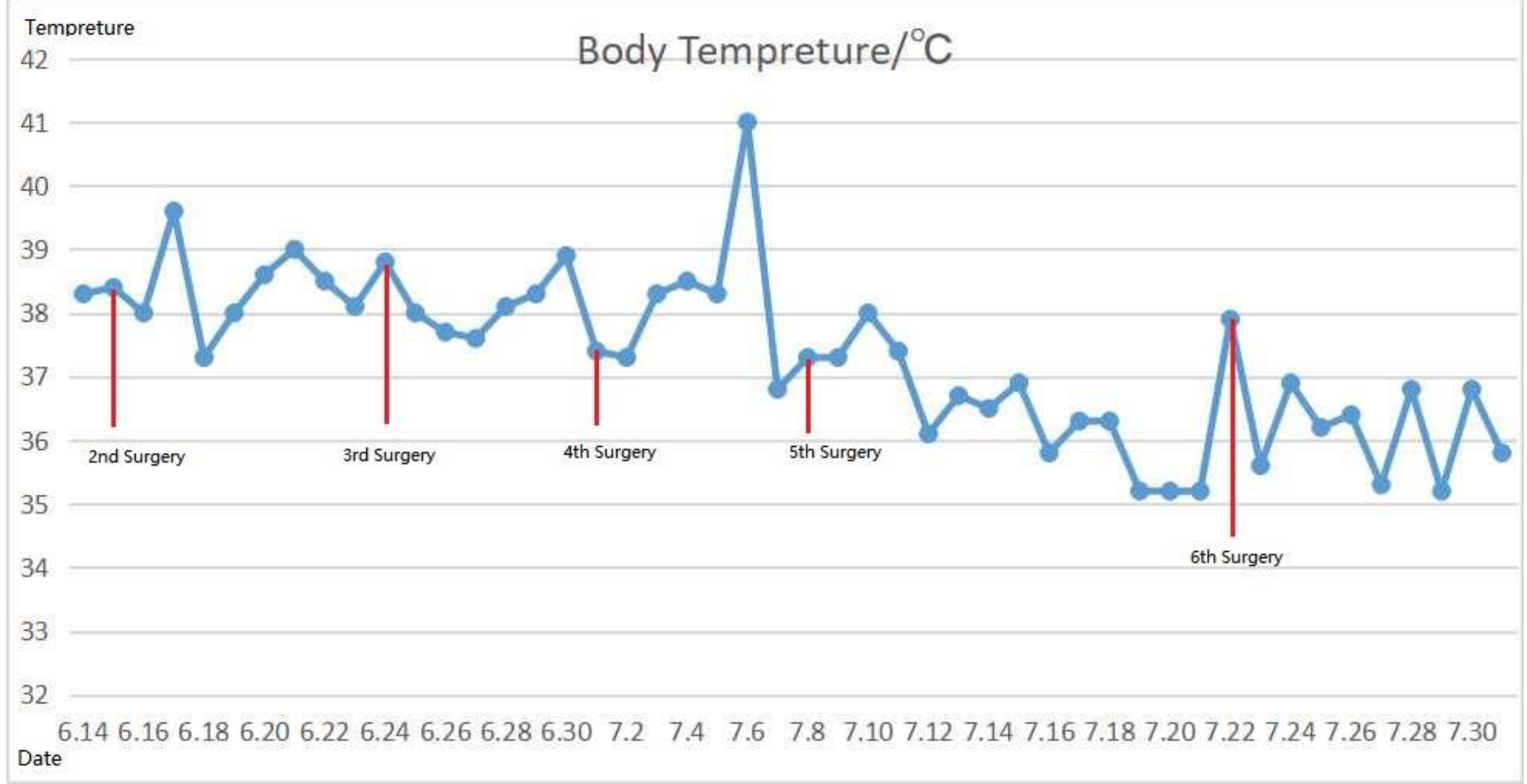

\section{Figure 9}

Please see the Manuscript file for the complete figure caption

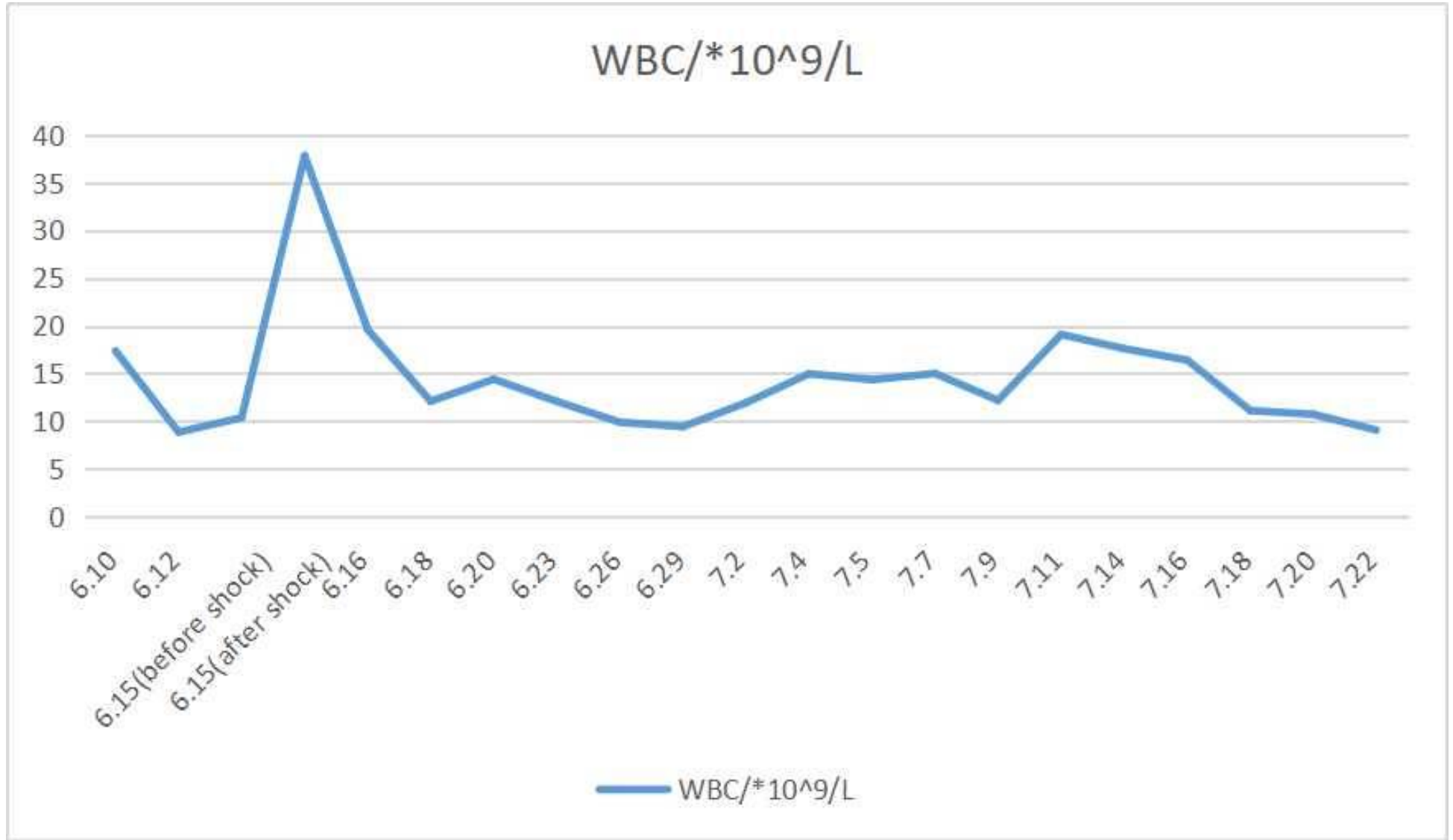

Figure 10 
Please see the Manuscript file for the complete figure caption 